\title{
Türk Spor Örgütlerindeki Kurumsal İletişim Çalışmalarının İncelenmesi: Futbol, Basketbol, Voleybol Branşları Örneği*
}

\author{
Esra ADIGÜZEL ${ }^{* *}$ \\ Cem TINAZ ${ }^{* * *}$ \\ AytekinALPULLU****
}

\section{Öz}

$\mathrm{Bu}$ çalışmanın amacı, spor örgütlerinin kurumsal iletişim çalışmalarına açıklık getirilerek daha net anlaşılması sağlandıktan sonra futbol, basketbol ve voleybol branşlarında yapılan uygulamaların değerlendirilmesini kapsamaktadır.

Bu doğrultuda yapılan literatür taramasının ilk aşamasında kurumsal iletişim ile ilgili temel unsurlar ele alınmıştır. Kurumsal iletişim kanalları ve tercih edilen araçlar başlığı incelenmiştir. Diğer aşamalarda ise daha detaya inilerek kurumsal iletişimin boyutları ve paydaşları hakkında kapsamlı bilgi verilmiştir. İç iletişimde üst yönetim, yönetim kurulu ve çalışanların görev alanları belirtilerek özellikle basketbol ve voleybol branşlarında yönetim kurulu ele alınmıştır. Dış iletişim de ise medya, pazarlama, sponsorluk/ kanallar/platformlar detaylandırılmıştır.

Üçüncü bölümde ise iç ve dış paydaşlar irdelenmiştir. İç paydaşlarda teknik direktör, antrenörler, personel, sporcular, hakemler incelenmiş, dış paydaşlarda ise taraftarlar, spor vakıfları, devlet ve diğer otoriteler ile kuruluşlar hakkında bilgi verilerek bu bölüm tamamlanmıştır.

Bu çalışmada yüz yüze görüşme tekniği ve nitel inceleme yöntemi tercih edilmiștir. Bundan dolayı futbol, basketbol, voleybol branşlarında başarılı olan 6 spor kulübünün kurumsal iletişim faaliyetleri ele alınmıştır. Yapılan çalışma sonucunda, spor kulüplerinin bu alanda önemli faaliyetlerde bulunduğunu ancak yeterli düzeyde bütçe ayrılmadığını, karşılaşılan engel ve problemlerin üstesinden gelmek adına yapılan uygulamalar da yetersiz kalındığı sonucuna varılmıştır.

Bu bağlamda spor kulüplerinin kurumsal imajlarını yaratabilmek adına daha profesyonel çalışmalar içerisine girmeleri gerekmektedir.

Anahtar kelimeler: Spor Kulübü, Kurumsal İletişim, İmaj

* $\quad$ Bu araştırma Esra Adıgüzel’in Bahçeşehir Üniversitesi Spor Yönetimi Bölümünde Yüksek Lisans Tezi olarak hazırlamış olduğu, “Türk Spor Örgütlerindeki Kurumsal İletişim Çalışmalarının İncelenmesi: Futbol, Basketbol, Voleybol Branşları Örneği” isimli çalışmadan türetilmiştir.

** Bahçeşehir Üniversitesi, Spor Yönetimi Bölümü, esraadigüzelll@gmail.com

*** Yrd.Doç., Bilgi Üniversitesi Spor Bilimleri ve Teknolojisi, cem.tinaz@bilgi.edu.tr

**** Yrd.Doç., Marmara Üniversitesi Spor Bilimleri Fakültesi, aytekin.alpullu@marmara.edu.tr 


\title{
Examination of Corporate Communication Applications in Turkish Sports Organizations: Examples of Football, Basketball, and Volleyball
}

\begin{abstract}
The aim of this study is to evaluate the application of corporate communication within various sport organizations. Branches of sport covered in this study include football, basketball and volleyball. In the first stage of the literature research, the main factors related to corporate communication were discussed.

Specifically the headings"corporate means of communication" and "preferred means" were reviewed.

During other phases of the study however, the details of corporate communications and stakeholders were thoroughly scrutinized. Within internal communication, top management, the board of directors and the employees' areas of responsibility were specified. Specifically in basketball and volleyball branches the board of directors were detailed. In regards to external communication, media, marketing, sponsorship / channels / platforms are described.

The third part of the research examines internal and external stakeholders. This section was completed by means of providing information about technical directors, coaches, personnel, athletes, and referees as the internal stakeholders and fans, sports foundations, state and other authorities and organizations as external stakeholders.

In this phase of the study, a face-to-face interview technique and qualitative examination method were preferred.

Therefore, corporate communication activities of 6 different sports clubs, successful in football, basketball and volleyball branches were discussed.

As a result of the study, it was concluded that the sports clubs had important activities in this area but lacked sufficient budget and the practices employed to overcome various encountered obstacles and problems remain inadequate.

In this context, sports clubs need to work more professionally in order to create their corporate image.
\end{abstract}

Keywords: Sport Club, Corporate Communications, Image

\section{GiRiş}

Kurumsal iletişim, kurum ve bireysel yapılar arasındaki birbirine bağlı etkilerden oluşmaktadır. $\mathrm{Bu}$ oluşum bağımsız ilişkilerin bir ağıdır. Kurumsal iletişim ile ilgili yapıları, çalışanlar, medya ve hissedarlar olarak sıralayabiliriz. Kurumsal iletişim, yatırımcılar, kurumsal ve pazarlama yönlü halkla ilişkiler, çalışanlar ve işe yeni başlayanlar ile iletişim, kurum içi, medya, kurumsal reklam ve çevresel iletişim gibi kurumsal boyutu kapsamaktadır (Elden ve Yeygel 2006). Örgütsel iletişim, kurumlarda yönetim aracı olarak kullanılmalıdır. Planlama ve idarede kurumsal iletişim, profesyonel bir alan olarak belirlenmeli, uygulamada ise kuruluşun bütün çalışanları tarafından üstlenilmelidir (Okay, 2003). Bundan dolayı da spor kulüplerinde kurumsal iletişim, örgütlü, amaçlı ve anlamlı sonuçlar elde etmek için tasarlanmış oldukça önemli, bütünleştirici bir dönem olarak kabul edilmelidir (Kasap ve Kesim, 2007).

Günümüzde spor, toplumlara itibar kazandırmak, çeşitli olaylara tepki verebilmek, siyasi rejimlerin propagandasını yapmak ve ekonomik açıdan kazanç sağlamak için vazgeçilmez bir unsur olarak karşımıza çıkmaktadır. Spor artık sadece sağlık amaçlı yapılan bir faaliyet olmaktan 
çıkmış, toplumsal ve ekonomik amaçları olan, ülke ekonomisine gelir sağlayan bir sektör haline gelmiştir (Argan ve Katırcı, 2008). Bu gelişimlere bağlı olarak spor örgütlerinin özellikle son yıllarda kazanmış olduğu başarılı sonuçlar paralelinde kurumsallaşma çalışmalarının hız kazanması, ekonomik olarak bütçelerinin artması kurumsal iletişimi profesyonel bir birim haline getirmiştir. Kulüplerin daha önce bu alanda etkin, donanımlı çalışanları bulunmazken, stratejileri doğrultusunda ilerlemeleri ile bu birim de oldukça önem kazanmıştır.

$\mathrm{Bu}$ çalışmada, spor kulüplerinde gerçekleştirilen kurumsal iletişim faaliyetleri ile futbol, basketbol ve voleybol branşlarında kurumsallaşmış, müsabakalarda yer alan Fenerbahçe, Beşiktaş, Eczacıbaşı, Yeşilyurt, Anadolu Efes ve Galatasaray kulüplerinin kurumsal iletişim alanındaki çalışmaları incelenmiştir. Bu kapsamda kurumsallaşmış kulüplerin, kurumsal iletişim faaliyetleri incelenmiş ve yapmış oldukları bu çalışmaları hangi hedefler doğrultusunda yaptıkları ve bu faaliyetleri profesyonel olarak nasıl yönettikleri, kendi departmanını oluştururken nasıl örgütlendikleri, kurumsal iletişim kapsamında hedef kitlelerinin kim olduğu sorularının cevapları aranmış ve belirlenen hedef kitlelere yönelik yapılan kurumsal iletişim çalışmaları ele alınmıştır.

Futbol, basketbol ve voleybol branşlarına bakıldığında son yıllarda artan başarılar sonucunda yeniden yapılanma söz konusudur. Geçmişte kurumsal iletişim alanında bir departman ya da konu ile ilgili uzman yöneticiler bulunmuyor iken, bu branşlarda uluslararası başarılar sağlanması, ekonomik olarak daha çok gelir elde edilmesi ve bu başarılar sonucunda medyada daha fazla yer bulunmasından ötürü yeniden yapılanma zorunlu kılınmıştır.

Bu çalışmanın amacı, ülkemizde futbol, basketbol ve voleybol branşlarında önde gelen kulüplerden elde edilen bilgi ve verilere dayalı olarak ortaya çıkan bulgular ışı̆̆ında, spor örgütlerinin kurumsal iletişim alanında yapmış olduğu çalışmaların ve bunların kulüplere sağlamış olduğu faydaların ortaya konmasıdır. Araştırma sonucunda elde edilecek bulguların, spor örgütlerinde yapılacak kurumsal iletişim çalışmalarına yön verecek ve geliştirecek, kurumunu maddi ve manevi daha ileriye taşıyacak olan çalışmalara katkı sağlaması beklenmektedir.

\section{TEORIK ÇERÇEVE}

İletişim, insanların toplumsallaşmalarının bir sonucu olarak ortaya çıkmaktadır (Çağlar ve Kılıç, 2006). Toplumda ya da kurumda bireyin kendisinden önce uygulanan kuralların farkına varması, değer ve inançları sahiplenmesi ve bunlar doğrultusunda kendine verilen rolleri öğrenmesi ve oynaması yani toplumsallaşması yalnızca iletişimle gerçekleşir. İletişim, kişiler arası ilişkilerin, başka bir değişle insan ilişkilerinin her alanını, kurumları ve giderek toplumları yaratan ve bir arada tutan "harç" işlevi görmektedir (Aktan, 2006).

Kurumların çalışanlarıyla arasındaki iç iletişim ve diğer paydaşları ile kurulan dış iletişimin biçimi, iletişim anlayışı ve iletişimde kullanılan kanallar, kurum kimliğinin şekillendirilmesi ve anlam kazanmasında büyük bir öneme sahiptir. Örgütsel iletişim olarak da açıllanabilen bu süreç, kurumların kendilerini hedef kitlelerine ifade ettikleri bir alan olarak kurum kültürü ve kurum 
kimliği kavramlarının ortaya çıkması ve yansıtılmasında önemli bir etkiye sahip olmaktadır (Elden ve Yeygel, 2006).

Kurumları, birbirleriyle sürekli ve düzenli iletişim kuran insanların oluşturduğu ağlar olarak düşünebiliriz. Tüm kurumlarda iletişim yatay ve dikey, resmi ve gayri resmi, içsel ve dışsal olarak gerçekleşebilir. Bu iletişimler sayesinde kurum çalışanları, yönetimin çeşitli kademeleri arasında ve kurumun dış çevresiyle bağlantısı sağlanır. Kurumdaki bu iletişimlerin tamamı iş amaçlı olmak veya kurumun ticari amaçlarını gerçekleştirilmesini sağlamak zorunda değildir (Uztuğ ve ark., 2012). Okay (2003) kurumsal iletişimi şu şekilde tanımlamıştır: "Kurumsal iletişim, kuruluşa, derneğe, kuruma veya organizasyona karşs, kamuoyunu ve işletme iklimini etkileme hedefi olan tüm iletişim tedbirlerinin sistematik bir biçimde kombine edilerek uygulanmasıdır. Kurumsal iletişim uzun vadeli uygulanan bir iletişimdir ve hedefi de bir imaj oluşturmak, korumak veya değiştirmektir”.

Teknolojideki hız ve iletişim alanında yaşanan gelişmeler ile birlikte bilgi edinmek, bilgi sahibi olmak her şeyin başında gelmektedir. Bilgi çağı, bilginin temel kaynak olduğu, bilgi üretimi ve iletiminin yaygınlaştığı, bilginin sürekli geliştiği ve buna bağlı olarak sürekli bilgilenmenin kaçınılmaz olduğu yeni toplumsal ve ekonomik dönemi belirtmektedir (Er, 2008). Kurumsal iletişim kanalları, yapısal olarak biçimsel (formel) ve biçimsel olmayan (informel) iletişim kanalları olarak incelenmektedir. Biçimsel iletişim kanallarını da kendi içinde inceleyecek olursak dikey (yukarıdan aşağıya ve aşağıdan yukarıya), yatay, çapraz ve dışa dönük iletişim olarak sınıflandırılabilir (Akhüseyinoğlu, 2010). Biçimsel iletişim, kurumsal kurallar içinde ve kurumun amaçları yönünde, önceden belirlenmiş bir tarzla gerçekleştirilen iletişimdir. Kurum üyelerinin kişiliklerinden soyutlanmış, statüler arası bir iletişim türüdür (Sabuncuoğlu ve Gümüş, 2008). Burada amaç, kurum için gerekli bilgi akışı ile görev ve sorumlulukların tam olarak yerine getirilmesini sağlamak, çalışanların işten memnun olmaları için istenen tutumu oluşturmak ve işleyişin sürekliliği için bilgi üretmektir (Yargıc1, 2010). Dikey iletişim kanalları ise bir kurum içinde, üst yönetim ve alt kademe çalışanlar arasında gerçekleştirilmesi beklenen bilgi aktarımı, üst yönetimin verdiği emirlerin ilgili çalışanlara ya da departmanlara ulaştırılması noktasında kullanılan iletişim kanallarıdır. Bu kanalların hızlı bilgi akışını gerçekleştirecek şekilde biçimsel iletişim yapıları ile işlemesi beklenmektedir.

İyi yönetilen bir kurumsal iletişim sayesinde, çalı̧sanların hem moral ve motivasyonunda hem de çalıştıkları kuruma karşı olan tutumlarında olumlu ve fark edilir düzeyde bir düzelme ve pozitif ortam görülür. Kurumun kendisi ve hedefleri açısından gelişme sağlanır, kurum içerisindeki ekipler arasında anlaşmazlık ve çıkar çatışması azalır, üretkenlik ve motivasyon artar (Okay, 2003).

Kurumsal iletişim araçları kendi içerisinde yazılı, sözlü ve elektronik olarak ayrılmaktadır. Yazılı iletişim, yönetsel etkinliklerin büyük çoğunluğunu gerçekleştirir. Bazı mesajları daha sonraki aşamalarda kontrol etmek ya da bilgi edinilmek üzere, nispeten kalıcı olarak düzenlenmeleri gerekir (Tutar, 2009). Kurumun rutin faaliyetleri esnasında üst ast tarafından oluşturulan strateji, 
politika, talimatlar ve emirler kurum içerisinde örgüt içi yazışmalar yoluyla alt kademelere aktarılmaktadır. Aynı şekilde alt kademelerdeki etkinliklere ilişkin rapor ve dokümanlar yine yazışmalar yoluyla yöneticilere iletilmektedir (Çetinkaya, 2007). Yazılı araçların kaynağa sağladığı en önemli özellik, iletilerin içeriğinin alıcıya gönderilmeden önce rahatça kontrol edilebilmesidir. Dergi, broşür, gazete, basın bülteni gibi tüm yazılı araçlar bu sınıfta incelenebilir. Sözlü iletişim araçlarına göre geri bildirim imkanlarının sınırlı olması ise yazılı iletişimin negatif yanıdır (Bıçakçı, 1998). Sözlü iletişim araçları, iletişimin daha hızlı ve daha etkili bir şekilde gerçekleşmesine olanak sağlar. Başka bir deyişle, iletişimin hedefine daha kolay ulaşmasını sağlamış olur (Çağlar ve Kılıç, 2006). Duyurular, basın toplantıları, konferanslar, bu kapsamda yer almaktadır. Sözlü iletişim araçlarını aşağıdan yukarıya, yukarıdan aşağıya ve yatay iletişim araçları olarak incelenebilir. Sözlü iletişim araçları içinde en fazla tercih edilen ve etkin olarak kullanılan araçlar görüşme ve toplantılardır (Çağlar ve Kılıç, 2006). Bu tür programlar iki kişi arasında oluşan iletişimden, toplantılara kadar geniş bir alanı kapsamaktadır. Bu iletişimlerin en belirgin özelliği yanlış anlaşılma riskinin minimum seviyede olmasıdır. Kimi örgütler açısından çalışanlar ve üst astların bir araya gelerek düşüncelerini paylaştığı, soruların dile getirildiği, şikayetlerin iletildiği ortamların olmasından dolayı toplantılar, iletişim stratejisinin temel taşıdır (Peltekoğlu, 2007). Bu tür araçların bir diğeri de toplantılardır. Kurumların hedeflerini gerçekleştirebilmesi, büyük ölçüde çalışanların inanç ve desteğini kazanmaya bağlıdır. Kurum içinde bireysel amaçlarla kurumsal amaçların birleştirilmesi, çalışanların kararları uygulamaya ve denetime destek vermelerini gerektirir. Bu bakımdan toplantılar, çift yönlü etkin bir iletişim yöntemi olarak oldukça önemli bir işleve sahiptir (Gürgen, 1997).

Kurumun iç ve diş çevresi ile olan etkileşiminde iletişim önemli bir araç niteliğindedir. Üst düzey yönetici olsun ya da alt düzey bir çalışan, kurum üyelerinin diğer işlerini yaptıkları zaman gerek duydukları bilgiler veya her tür mesaj kurum içi iletişim olarak kabul edilebilir. Dış iletişim, kurum çalışmalarını yürütürken, bir amaç için kurumun dış çevresi ile gerçekleştirdiği iletişimdir (Tutar, 2009).

Son yillarda spor kulüpleri kurumsal yönetimin temel ihtiyaçlarından biri olarak iç ve diş çevrelerindeki bütün öğeleri kapsayan bir ilişki ağ1 geliştirmekte ve bu ilişkiyi çağdaş yönetim unsurlarıyla yönetmektedirler. Kulüplerin iç ve dış çevreleri ile oluşturdukları bağlarda iletişim yönetimi ve/veya kurumsal iletişim olarak belirtilen yapı ile karşılaşılmaktadır (Katırcı, 2007). $\mathrm{Bu}$ iletişim türüne dahil olanlar kurumun çalışanlarıdır. İş görenler kurumu hem içeriden hem de dışarıdan izledikleri için kurum adına önemli bir etkiye sahiptirler (Okay, 2003). Kurum içi iletişim, kısa hatırlatma notları, raporlar, teklifler, toplantılar, sözlü aktarımlar, konuşmalar, kişiler arası ve telefonda yapılan görüşmeler gibi yazılı ya da sözlü yollarla yapılan iletişimi içerir. İç iletişim yardımcı iş görenler arasında hatta üst astlar arasında oldukça önemli bir etkiye sahiptir. İç iletişim sorunların belirlenmesini ve çözüm alanlarının bulunmasını sağlar. Ayrıca karar almaya ve politika ortamı yaratmak adına zemin oluşturmaktadır (Gülnar, 2007). Spor kulüpleri; yönetim birimleri, teknik kadro, sporcular ve hizmet personelinden meydana gelen bir kurum içerisinde etkinlik göstermektedirler. Bu yapıda spor kulübü yönetimlerinin kendisi ve iş 
görenler arasındaki bağları arttırmak için yaptığı çalışmalar önemlidir. Spor kulüplerinde etkili bir kulüp içi iletişim süreci bu bağları arttırmada önemli bir yere sahiptir (Katırc1, 2007).

Bir kurumda iletişimin zayıf olması, iş görenlerin performans seviyesinin düşmesi, işe olan bağlılı̆̆ın azalması, kurumsal stres ve çatışmanın oluşması, kalite seviyesinin düşmesi, hizmet ve üretimde yaşanan engeller, müşteri şikayetlerinin fazlalaşması vb. sorunları oluşturmaktadır (Güriz ve Özdemir, 2007). Spor kulüplerinde başarılı bir iç iletişim sağlayabilmek için düzenli toplantılar yapmak, sosyal aktiviteler hazırlayarak kulüp içerisinde bağlılık duygusunu ve beraberliği geliştirmek, iş görenlerin düşüncelerini iletme imkanı sunmak, kulübün amaçları belirlenirken çalışanlarını amaç belirleme kısmına dahil etmek gibi farklı yollar kullanılabilir. $\mathrm{Bu}$ yollar kulübün içsel durumunu olumlu etkileyerek iş görenler arasında bağları arttıracaktır (Katırc1, 2007). Bir spor yöneticisinin sektörde belirlediği kurumsal amaçlara erişebilmesi için; sporu tanıması, spor kurumunun bulunduğu çevreyi anlaması, insan kaynağını önemli ölçüde kullanabilmesi ve performansı en üst seviyede elde edebilmek için gerekli önlemleri yerinde ve zamanında 1sağlayabilmesi gerekir (Basım ve Argan, 2009).

Kitle iletişim araçları içinde spor ile ilgili oldukça fazla içerik bulunmaktadır. Spor gazeteleri, spor dergileri, günlük gazetelerin arka sayfaları, televizyon programları, spor haberleri, naklen maçlar, maç özetleri, spor tartışma programları derken medyanın spor sektöründe büyük bir takipçi kitlesine sahip olduğu anlaşılmaktadır (Dever, 2010). Spor sektöründeki olayları insanlara ileten önemli unsurlardan biri yazılı basındır. Teknolojinin hızlı bir şekilde gelişmesi, iletişim araçlarının çeşitlenmesine ve pazarlama iletişiminde bütünleşik bir bakış açısının oluşmasını sağlamıştır. Gazete, radyo ve televizyon haricinde farklı görsel ya da işitsel iletişim kanalları oluşturulmuştur.

Spor kulüplerinin iç ve dış çevrelerinde etkileşim içerisinde olduğu unsurları kulüplerin paydaşları olarak belirtebiliriz. Bundan dolayı, spor kulüplerinin temel paydaşlarının; taraftarlar, kulüp üyeleri, yayıncı kuruluşlar, finansal kuruluşlar, sponsorlar, yerel yönetimler, topluluklar, ulusal ve uluslar arası yasa koyucular olduğu düşünülmektedir. Spor kulüplerinin belirtilen paydaşları arasında müşteri statüsünde bulunan kesimin taraftarlar olduğu gözükmektedir. Bundan dolayı, kulüp-taraftar iletişiminin özenle yönetilmesi temel bir zorunluluktur (Katırc1, 2009). Spor örgütlerinin klasik anlamdaki iç paydaşlarını yönetim kurulları, teknik heyet ve diğer çalışanlar olarak nitelendirebiliriz. Klasik anlamdaki dış paydaşlar ise taraftarlar, idari örgüt temsilcileri (federasyon vs.), hakemler, kamuoyu olarak nitelendirilebilmektedir.

\section{YÖNTEM}

$\mathrm{Bu}$ araştırmada nitel araştırma yöntemlerinden derinlemesine görüşme tekniği kullanılmıştır (Tinaz, 2011). Nitel araştırma gözlem, görüşme ve doküman analizi gibi nitel veri toplama yöntemlerinin kullanıldığı, algıların ve olayların doğal ortamda gerçekçi ve bütüncül bir biçimde ortaya konmasına yönelik nitel bir sürecin izlendiği araştırma olarak tanımlanabilir (Yıldırım ve Şimşek, 2011). Nitel araştırmalarda elde edilen bilgilerin analizi, nicel araştırmalarda elde 
edilen bilgilerin analiz edilmesinden oldukça farklıdır. Çünkü görüşmelerden, gözlemlerden, dokümanlardan, farklı nitelikte bilgiler elde edilir (İslamoğlu ve Alnıaçı, 2013).

Çalışmanın evrenini Türkiye'de futbol, basketbol, voleybol branşlarında mücadele eden kulüplerin kurumsal iletişim alanında yetkili olan yöneticileri kapsamaktadır. Bu branşlar incelendiği zaman özellikle son yıllarda kazanılan başarılar ile kurumsal iletişim alanında daha fazla çalışmalara yer verildiği ve yatırımlar yapıldığı gözükmektedir. Bundan dolayı, örneklemin futbol, basketbol ve voleybol branşlarında bulunan yetkililerin katılması uygun görülmüştür. Bu kapsamda uygun görülen 6 kulüp ile görüşülmesi planlanmıştır. Belirlenen kulüplere ile telefon veya mail ile ulaşılmış, ancak bu kulüpler arasında voleybol branşı için ulaşılan Vakıfbank, banka ve spor kulübü kuralları gereği talebe olumlu yanıt verememiştir. Bundan dolayı bu branş için Eczacıbaşı Spor Kulübü ve Yeşilyurt Spor Kulübü ile görüşme yapılmıştır. Görüşmeler 2014 yılının Şubat ve Mayıs ayları arasında yapılmıştır. Görüşmeler dijital kayıt cihazına kaydedilmiş ve daha sonra yazıya dökülmüştür. Kayıt işlemi başlamadan önce yetkiliden sözlü olarak onay alınmıştır. Görüşme öncesi ise tez konusu kapsamlı bir şekilde kulüp yetkilisi ile paylaşılmıştır. Çalışmada, görüşülen kulüplerde kurumsal iletişim alanındaki yetkili kişi ile yapılan 30-50 dakika süren yüz yüze görüşmelerde, 7 tane soru sorulmuştur. Sorular spor örgütlerinin kurumsal iletişim anlamında gerçekleştirdikleri faaliyetlere, ulaşılması planlanan hedef kitlelere, kullanılan iletişim araçlarına, ortaya çıkan etkinin ölçümlenmesine ve bu faaliyetler için ayrılan bütçeye dair detaylı bilgi edinmek üzere açık uçlu olarak düzenlenmiştir. İçerik analizinde elde edilen bulgular derinlemesine incelenerek, kodlama yaklaşımı tercih edilmiştir. Bu doğrultuda görüşme için hazırlanan sorular tezin ana konusunu teşkil ederken, görüşme esnasında verilen cevaplar verileri inceleme sürecinde alt unsurlarını oluşturmuştur. Görüşmelerin belirlenen temalar ışığında incelenecek ve farklı kişilerin görüşlerinin karşılaştırılmasına olanak sağlanmıştır. Bu araştırmanın güvenirliğini sağlayabilmek için araştırma örneklemine katılan kişiler titizlikle seçilmiştir. Bu kişiler kendi bölümlerinde seçkin bir işgücünü kapsamaktadır. Örnekleme dahil olan bireylerin seçim kriterleri net bir şekilde ortaya konulmuştur. Veri toplama ve analiz bölümleri ayrıntılı şekilde aktarılmıştır.

\section{BULGULAR}

Bu araştırmanın ana temasını Türkiye’deki spor kulüplerinin kurumsal iletişim çalışmaları teşkil etmektedir. Bununla birlikte ülkemizde spor kulüplerinin kurumsal iletişim faaliyetleri içerisinde profesyonelce yapmış oldukları uygulamalar, bu uygulamalarının tercih edilme nedenleri, uygulamalar sonucu ulaşmak istedikleri hedef kitle, bu uygulamaları gerçekleştirirken karşılaşmış oldukları engeller ve problemler, kurumsal iletişim çalışmalarının ölçümleme konusunda neler yapıldığ 1 gibi konularda bilgi edinilmesi hedeflenmiştir. 6 kulüp yöneticisinden elde edilen bilgiler, betimsel analiz sürecinde aşağıdaki ana temalar doğrultusunda görüşmelerden temel ifadeler alıntılanarak gruplandırılmıştır. Farklı cevapların alındığı sorularda her kulüp için ayrı ayrı temalar dikkate alınarak betimlenmiştir. Benzer cevapların alındığı durumlarda ise genel durumun betimlenmesi için bazı alıntılar yapılmıştır. 
Futbol branşında yer alan spor kulüplerinin faaliyetleri incelendiğinde Fenerbahçe ve Beşiktaş kulüplerinin medya için ajanslar ile çalışmayı tercih ettiği görülmüştür. Ayrıca futbol branşının önemli spor kulüplerinden biri olan Fenerbahçe’nin belirtmiş olduğu gibi kurumsal iletişim uygulamaları kapsamında Türkiye Futbol Federasyonu, her kulübün medya sorumlusu olmasını gerekli kılmıştır. Bundan dolayı Fenerbahçede kurumsal iletişim sorumluları aynı zamanda medya sorumlularıdır. Bunun dışında futbol maçlarının öncesi ve sonrasında federasyonun ya da yayıncı kuruluşun şartlar ne olursa olsun yerine getirilmesini istediği bazı normlar vardır. Örneğin Türkiye Süper Toto Süper Lig'de maçlardan önce belirli bir saat diliminde hoca ve kadrodaki bir oyuncu, maçtan sonra yine yayıncı kuruluş hoca ile birlikte iki tane oyuncu basın toplantısı yapmakla yükümlü ve geçen yıl itibari ile basın toplantılarında masaya oturma mecburiyeti bulunmaktadır. Spor kulüpleri kurumsal iletişim alanında takımlarının sevilen oyuncuları ile çalışmalar gerçekleştirmektedir. Voleybol branşında ise, kurumsal iletişim faaliyetleri kapsamında birtakım etkinlikler düzenlemesi aracılığıla takımın sevilen ve başarılı oyuncularının taraftarlar ile bir araya gelmesi sağlamaktadır. Sosyal medya için ajanslar ve medya takip sistemi ile ortak çalışmalar yapıldığg belirtmiştir. Basketbol branşında ise fan karta sahip olan taraftarlarının takım oyuncuları ile deplasmanlara gitmesi sağlanarak, yemek organizasyonları düzenlenerek kurumsal iletişim faaliyetlerinde bulunulmaktadır. Öte yandan Galatasaray'da son yıllarda kurumsal iletişim çalışmalarına her ne kadar ağırlık verse de, sporcular ve taraftarlar nezdinde yapılan kapsamlı çalışmaları bulunmamaktadır.

Araştırma kapsamında görüşülen kulüplerin kurumsal iletişim uygulamalarını takip eden birimler farklılık göstermektedir. Bu farklılıklar aşağıda kulüp bazında değerlendirilmiştir.

- Fenerbahçe Spor Kulübü yetkilisi, kurumsal iletişim faaliyetlerini son derece merkezi şekilde konumlandırdıklarını ve kulübün hem iç hem de dış paydaşları ile sürekli olarak ve bir plan doğrultusunda iletişime geçildiğini belirtmiştir. Kulübün kurumsal iletişim departmanı, kulübün her türlü iletişim faaliyetlerini düzenleyen, stratejilerini üreten hatta daha çok kriz dönemlerinde stratejiler belirleyen departmanıdır.

- Eczacıbaşı Spor Kulübü yetkilisi, kulübün 50 yıldır faaliyet gösterdiğini ve bu 50 yıl içerisinde kurumsal iletişimin her zaman yüksek önem taşıdığını belirtmiştir. Bu işin sosyal sorumluluk dışında tanıtımının da çok önemli olduğunu ifade etmiş ve kulübün temel amacının voleybolu geliştirmek, geniş kitlelere sevdirmek olduğunun altını çizmiştir. Eczacıbaşı Spor Kulübü’nün medya planında gazeteler çok önemlidir; bu yüzden gazetecilerle yapılan yurtdışı seyahatleri ile onları voleybola çekmek ve onlara voleybolu sevdirmek amaçlanmaktadır.

- Anadolu Efes Spor Kulübü yetkilisi ise kurumsal iletişim faaliyetlerinin kurgulanması ve yönetilmesi için 10'un üzerinde ajansla çalıştıklarını belirtmiştir. Kulübün fotoğraf ajansı, video ajansı, sosyal medya ajansımız, web tasarımızı yapan ve en önemlisi bütün saha işlerimizi yapan etkinlik ajansı bulunmaktadır. Anadolu Efes Spor Kulübü’nün diğer spor kulüplerinden farklı olarak hiçbir zaman gerçek anlamda sponsorluk çalışması olmamaktadır. Esas destek Anadolu Grubu tarafından sağlanmaktadır. 
- Yeşilyurt Spor Kulübü’nde ise diğerlerine göre daha kısıtlı uygulamalar söz konusudur. Kulüp menajeri, iç iletişim kapsamında oyuncuların transferi de dahil olmak üzere oyuncu menajerleri ile görüşme, transfer işlemlerin yürütülmesi, oyuncu yabancı ise vize işlemleri, ev ya da lojman işlemlerinin yapılması gibi konuları kapsayacak bir odakta yürütülmektedir. Kulüp kurumsal iletişim faaliyetleri kapsamında alt yapıya dikkat çekerek, gazeteciler ile diyalog halindedir, çeşitli voleybol programlarında kulüp ve spor branşı hakkında bilgi vererek iletişim çalışmaları sürdürülmektedir.

- Galatasaray Spor Kulübü yetkilisi, özellikle son iki yıldır kurumsal iletişime daha çok önem verdiklerini belirtmiştir. Kurumsal iletişim uygulamaları kapsamında düzenli olarak çalışmalar yapıldığı, toplantılarda geri dönüşler alınarak yol haritası çizildiği açıklanmıştır. Ayrıca yapılan çalışmalar ile ilgili personellerin düzenli olarak mail ya da diğer iletişim araçları aracılı̆̆ı ile bilgilendirildiği belirtilmiştir.

Genel anlamda gerçekleştirilen kurumsal iletişim faaliyetlerinin, kulüplerin marka kimliği üzerinde olumlu etkileri olduğu sonucuna ulaşılmıştır. Yapılan çalışmalar ve kazanılan başarılar sayesinde kulüplerin medyada daha çok yer almaları ve uluslar arası alanda söz sahibi olabilmeleri sağlanmaktadır.

- Fenerbahçe Spor Kulübü’nde iletişim faaliyetleri, takımın yüksek popülariteye sahip olmasından ve birçok farklı eleştiriye maruz kalmasından ötürü marka kimliğinin kuvvetlendirilmesinden ziyade krizlerin doğru şekilde yönetilmesine yönelik gerçekleştirilmektedir. Bu faaliyetler gerçekleştirilirken kulübün birçok kez diğer kulüplerle ve basınla birlikte hareket etmesi gerekmektedir.

- Eczacıbaşı Spor Kulübü yetkilisi, takımın şirketler grubun içindeki konumuna bağlı olarak gerçekleştirilen iletişim faaliyetlerinin Eczacıbaşı’nın itibarına olumlu etki yapması hedeflenmektedir. Takımın, holding bünyesinde yer alan firmaların itibarına ve satışına etkisi olması da amaçlanmaktadır.

Kurumsal iletişim uygulamaları ile genel anlamda ulaşılmak istenen hedef kitle ve çalışanlara yönelik uygulamalara bakıldı̆̆ında Eczacıbaşı ve Anadolu Efes Spor kulüplerinin kurumsal iletişim adı altında belli bir hedefe ulaşmaktansa her yaştan her kesime ulaşmak istediklerini belirtmiştir. Ancak Eczacıbaşı ve Yeşilyurt Spor Kulüplerinin altyapıya önem vermelerinden ve voleybolun daha çok 10-16 yaş grubu arasındaki gençlerin ilgisini çekmesinden dolayı bun kitleye ulaşmanın daha önemli olduğu vurgulanmıştır. Spor kulüplerinin iletişimde tercih ettiği araçlar genel olarak aynıdır. Hem maliyetinin düşük olması hem de kısa sürede daha hızlı sonuca ulaşılması sosyal medyanın tercih edilme nedenlerini oluşturmaktadır. Bunların yanı sıra en büyük etkenlerden biri dijital dünyanın çok geniş kitlelere ulaşabilme özelliğidir. Ancak yukarıda da belirtildiği gibi kulüpler sosyal medya çalışmalarının takibi konusunda ayrılmaktadır. Fenerbahçe ve Galatasaray bu konuda kendi bünyesinde yer alan çalışanlarını tercih etmekte fakat Anadolu Efes medya takip sistemi ve çalıştıkları ajansların yönlendirmesi, belirlenen ortak 
stratejiler ile yol haritası çizmektedir. Yine Eczacıbaşı Spor Kulübü de halkla ilişkiler ajansı ile hareket etmektedir.

Sosyal medya alanının kullanımı dışında yapılan uygulamalarda bütçe konusu detaylı incelenmektedir. Futbol branşında yer alan spor kulüplerin bütçe olanakları daha zengin olmasından dolayı sosyal medya alanı dışında birçok iletişim kanalları da mevcuttur. Fenerbahçe, Galatasaray, Beşiktaş gibi kulüplerin kendilerine ait özel televizyon kanalları, düzenli basılan dergi, özel taraftar kartları, yüksek rakamlardan oluşan özel datalar, özel GSM hatları gibi geniş iletişim yelpazeleri bulunmaktadır. Anadolu Efes ve Eczacıbaşı Spor Kulüpleri’nin de kendilerine ait özel data, dergi gibi seçenekleri bulunmakta ancak içerik bakımından futbol kulüplerine nazaran çok geride kalmaktadırlar.

Tablo I: Kulüplerin kurumsal iletişim için tercih ettikleri araçlar

\begin{tabular}{|l|l|}
\hline Kulüp Adı & Kurumsal iletişim uygulamalarında tercih edilen araçlar nelerdir? \\
\hline Yeşilyurt Spor Kulübü (Voleybol) & Bilboardlar, tv, broşür \\
\hline Beşiktaş Jimnastik Spor Kulübü (Futbol) & $\begin{array}{l}\text { Beşiktaş TV, Beşiktaş dergi, facebook, twitter, resmi web sayfası, } \\
\text { Kartalcell, anlaşmalı banka kartları }\end{array}$ \\
\hline Fenerbahçe Spor Kulübü (Futbol) & $\begin{array}{l}\text { Fenerbahçe TV, Fenerbahçe dergi, facebook, twitter, instagram, resmi } \\
\text { web sayfası, özel üye dataları, Fenercell, anlaşmalı banka kartları }\end{array}$ \\
\hline Anadolu Efes Spor Kulübü (Basketbol) & Resmi web sayfası, facebook, twitter, Efes fan kart, \\
\hline Eczacıbaşı Spor Kulübü (Voleybol) & Kurum içi haberlerin yer aldığı kurum dergisi, tv, \\
\hline Galatasaray Spor Kulübü (Basketbol) & $\begin{array}{l}\text { Galatasaray TV, Galatasaray dergi, anlaşmalı banka kartları, özel üye } \\
\text { dataları, resmi web sayfası, facebook, twitter }\end{array}$ \\
\hline
\end{tabular}

Kurumsal iletişim uygulamalarında kurum içinde ve kurum dışında karşılaşılan engeller ve problemler ile bunların üstesinden gelmek için yapılan çalışmalara bakıldığında görüşülen Yeşilyurt ve Eczacıbaşı Spor Kulüpleri’nin yöneticilerinin bu konuda belirtmiş oldukları en önemli engel bütçedir. Voleybol branşının futbol ve basketbol branşlarının gerisinde kalmasından dolayı bazı finansal sıkıntıları vardır. Spor kulüplerin faaliyet gösterdikleri branşlara göre karşılaştıkları engeller de farklılık göstermektedir. Öncelikle basketbol ve voleybol branşlarında yer alan kulüplerin en önemli problemlerinden biri kısıtlı bütçedir. Futboldaki kadar yüksek gelirlerin olmaması ve toplumun genelinden ziyade belli bir kesime yönelebilmeleri, bu alanda kulüplere engeller yaratmaktadır. Kısıtlı ilgi kurumsal iletişim çalışmalarının şekillenmesinde önemli bir etken olmaktadır. 
Marmara Üniversitesi Spor Bilimler Dergisi / Marmara University Journal of Sport Science • Cilt I, Sayı 2, Aralık 20I6, ss. I-I4

Tablo 2. Kulüplerin kurumsal iletişim uygulamalarında kurum içinde ve kurum dışında karşılaştıkları engeller

\begin{tabular}{|l|l|}
\hline Kulüp İsmi & $\begin{array}{l}\text { Kurumsal iletişim uygulamalarında kurum içinde ve kurum dışında } \\
\text { karşılaşılan engeller ve problemler }\end{array}$ \\
\hline Fenerbahçe Spor Kulübü & Medya tarafından gerekli desteğin olmaması \\
\hline Galatasaray Spor Kulübü & $\begin{array}{l}\text { Medya tarafında yaşanan engeller, köklü spor kulübü olmalarından } \\
\text { dolayı yeniliklere kapalı olunması }\end{array}$ \\
\hline Beşiktaş Jimnastik Kulübü & $\begin{array}{l}\text { Yeniliklerin çabuk aşılanamaması, yüksek ücretli transferlerden dolayı } \\
\text { bütçe açığı }\end{array}$ \\
\hline Anadolu Efes Spor Kulübü & $\begin{array}{l}\text { Uzun yllar aynı kişilerin bulunmasından dolayı değişimlere kapalı } \\
\text { olması, son yllarda bütçe faktöründe yaşanan problemler }\end{array}$ \\
\hline Eczacıbaşı Spor Kulübü & $\begin{array}{l}\text { Voleybol branşına olan ilginin yetersiz olması, maç yayınlarına gereken } \\
\text { onemin verilmemesi }\end{array}$ \\
\hline Yeşilyurt Spor Kulübü & $\begin{array}{l}\text { Sponsor yetersizliğinden dolayı bütçe problemi, voleybol branşının } \\
\text { futbol ve basketbol branşının gerisinde kalması }\end{array}$ \\
\hline
\end{tabular}

Ölçümlemekonusunda sponsorlukönemlibir etken olarakgözükmektedir. Araştırmaörneklemleri arasında bu etkene en fazla önemi veren basketbol branşında faaliyet gösteren Anadolu Efes Spor Kulübü olduğu sonucu ortaya çıkmaktadır. Yapmış oldukları sponsorluk anlaşmalarının geri dönüşlerini ölçümlemekte ve alınan sonuçları detaylı olarak değerlendirmektedirler. Diğer kulüplerin de sponsor anlaşmaları bulunmakta ancak bunu bir ölçümleme sistemi bakımından ele almamaktadırlar. Aynı şekilde Anadolu Efes ve Eczacıbaşı Spor Kulüpleri holding bünyesinde yer aldıkları için ayrıca kurumsal itibar araştırması gerçekleştirilmektedir. Anadolu Grubu ve Eczacıbaşı Holding, şirket bünyesinde yapmış oldukları itibar araştırmaları spor kulüplerini de etkilemekte ve ulaşılan sonuçlar doğrultusunda çalışmalara yer verilmektedir.

Sosyal paylaşım sitelerinde çok fazla takipçiye sahip olan Fenerbahçe, Galatasaray ve Beşiktaş ölçümleme konusunda bu alanları tercih etmektedirler. Örneğin "twitter" üzerinden atılan bir tweetin ne kadar "retweet" aldığını ya da ne kadar geri dönüş aldığını, "Instagram” üzerinden gönderilen bir fotoğrafa ne kadar yorum geldiğini ve neler yazıldığı gibi uygulamalar aracılığ ile birer ölçümleme yaratmaktadır. Ancak Anadolu Efes Spor Kulübü ölçümleme konusunda bu uygulamayı çok doğru bulmamaktadır. Nedeni ise sağlıklı sonuçlara ulaşılamayacağına dair inançtır. Çünkü bu alanda yapılan iletişim ile güvenli bir veri olmamakta ve takip eden kişiler sadece o konu ile ilgili yorumunu ya da beğenisini belirttiği için diğer konular ile ilgili ne düşündüğü ya da nasıl tepki ile karşılaşılacağı bilinmemektedir. Spor kulüplerinin ölçümleme konusunda ortak noktada birleştiği konu bilet satışlarıdır. Maçlara olan ilginin ne düzeyde olduğu ne kadar bilet satıldığı ya da satılmadığı, takımın başarısı hangi düzeyde olduğunda bilet satışlarında değişiklik olmakta gibi ana temalar incelenmektedir. 


\section{SONUÇ}

Araştırma sonucunda elde edilen veriler literatürle desteklenerek açıklanmıştır. Araştırmanın sonuçları son kez özetlenmektedir;

- Günümüzde spor kulüpleri iletişim alanında daha aktif olabilmek, kurumsallaşmak adına önemli adımlar atmak için özellikle son yıllarda büyük ilerlemeler kaydetmiştir. Ancak ilerleme kaydetme sürecinde karşılaşmış oldukları bazı sıkıntılar mevcuttur. Birinci adımda en büyük engel bütçe olarak gözükmektedir. Spor kulüplerinin özellikle basketbol ve voleybol branşlarında faaliyet gösteren kulüpler iletişim çalışmalarında bütçelerini kısıtlı tutmak zorunda kalmaktadırlar. Bunun en büyük nedeni ise ülke olarak spor kültürünün gelişmemiş olması ve diğer ülkelerde de olduğu gibi futbol branşının çok daha fazla taraftar grubuna sahip olmasıdır. Şu şekilde belirtmek gerekir ise; basketbol ve voleybol spor kulüplerinin taraftar grupları az sayıda olduğu için futbol kulüpleri kadar başarılı çalışmalar yapılamamaktadır. Bu doğrultuda futbol, spor kulüpleri taraftarın ilgisini kaybetmemek ve her alanda olanaklarından yararlanabilmek için kurumsal iletişim alanında birçok faaliyette bulunmaktadır. Basketbol branşında Anadolu Efes ya da voleybol branşında Eczacıbaşı Spor Kulübü taraftara yönelik iletişim çalışmalarını Fenerbahçe kadar geniş yelpazede gerçekleştirememektedir. Bunun sonucunda da Fenerbahçe ve Beşiktaş’ın gerisinde kalmaktadır.

- Spor kulüplerinin kurumsallaşabilmeleri için pazarlama bütçesinde düzenli olarak yer alması gerekmektedir. Yüksek ücretlerde sporculara ödemeler yapılırken iletişim çalışmalarında kulüplerin daha kısıtlı bütçeler ile yapı sürdürülmeye çalışılmaktadır. Bu konu ile bağlantılı olarak çıkan sonuçlarda kulüpler iletişim biriminin çalışmalarına yeterli seviyede önem vermemektedir.

- Spor kulüplerinin iç iletişim alanına baktığımız zaman eğitim konusunda yetersiz kaldığını görmekteyiz. Bunun arkasında yatan en önemli neden, spor kulüplerinin kurumsallık adı altında son yıllarda çalışmalar gerçekleştirmesidir. Daha önceki dönemlerde kurumsal iletişim stratejiler içerisinde yer almaması ve diğer sektörde faaliyet gösteren kurumlar kadar önem verilmemesi üzerine bu alanda geri kalmaları söz konusu olmuştur. Ayrıca günümüzde yapılan çalışmalara bakıldığında ise yine yeterli bir sistem kurulmadığı gözükmemektedir. Başarılı bir kurumsal iletişim planlamasının yapılabilmesi için kurum olarak çalışanlar, üst yönetim, yönetim kurulunda bulunan kişilerin yeterli düzeyde donanıma sahip olması esas alınmalıdır. Kökleşmiş bir yapı çerçevesinde faaliyetlerine devam eden spor kulüplerinde yer alan personellerin birçoğu spor eğitimi konusunda yetersiz seviyede ya da bir spor geçmişi olmamaktadır. Bu bulgu doğrultusunda, spor kulüplerinin bu alana yönelik ciddi boyutlarda yapmış olduğu faaliyetlerden söz edilememektedir. Bu noktada kurumsal iletişim çalışmalarının düzenli olarak kulüp hedefleri içerisinde yer alması, bütçe alanında daha fazla pay ayrılması sonucunda kalıcı uygulamalar söz konusu olabilecektir. Çünkü sportif başarıların sağlanması da başarılı iletişim, reklam, pazarlama, sponsorluk gibi alt yapının 
olması sonucu ortaya çıkmaktadır. Bundan dolayı kurumsal iletişim yetkilileri çalışmalarını daha ileriye taşımak, uzun vadeli hedeflerde başarı sağlamak, kulübe daha fazla gelir getirebilecek işler yapmak istiyorlar ise adımların daha profesyonel atılması ve alt yapıya gereğinden fazla önem verilmesi gerekmektedir.

- Spor kulüpleri, kurumsal iletişim kapsamında yapmış oldukları ölçümleme sisteminde de yetersiz çalışmalar gerçekleştirmektedir. Son yıllarda sosyal medyanın hızlı büyümesi sonucu, Anadolu Efes Spor Kulübü dışında kalan kulüpler bunu bir ölçümleme aracı olarak kullanmaktadır. Ancak "twitter" da, spor kulübünün resmi sayfasında takip edenlerin sayısı ya da "Instagram" sitesindeki paylaşımı yapılan yorumlar sağlıklı sonuçlar veremeyebilir. Çünkü burada yapılan iletişim ile elinizde güvenli bir data olmamakta ve sizi takip edenler hakkında net bilgiler bulunmamaktadır. Bir başka değişle resmi sayfaya yorum yapan taraftarın sadece o konu ile ilgili düşüncelerini bilebiliriz ancak diğer konular ile ilgili ne düşündügünü ya da nasıl bir tepki ile karşılaşılacağı bilinmemektedir. Tabii burada bütçe planlaması doğrultusunda hareket edildiği için ek bir maliyet yaratılmaması adına sosyal medya tarafından dönüş almak kulüp için önem arz etmektedir. 


\section{KAYNAKLAR}

Akhüseyinoğlu, A., (2010). Kurumsal sosyal sorumluluk projelerinin yürütülmesinde kurumsal iletişim araçlarının etkisi. Yüksek Lisans Tezi. İstanbul: Marmara Üniversitesi SBE.

Aktan, C. C. (Ed.). (2006). Kurumsal kültür, organizasyonlar, kurallar ve kurumlar. Ankara: Sermaye piyasası kurulu.

Basım, N. \& Argan, M., (2009). Spor Yönetimi. Ankara: Detay Yayıncılık.

Argan, M. \& Katırcı, H., (2008). Spor pazarlaması. 2. Baskı. Ankara: Nobel Yayın Dağıtım.

Bıçakçı, İ., (1998). İletişim ve halkla ilişkiler. Ankara: MediaCat Yayınları.

Çağlar, İ. \& Kılıç S., (2006). Genel iletişim. Ankara: Nobel Yayın Dağıtım.

Çetinkaya, A., (2007). Kurumsal iletişim çerçevesinde karar destek sistemleri ve portal yönetimi. Yüksek Lisans Tezi. İstanbul: Marmara Üniversitesi SBE.

Dever, A., (2010). Spor sosyolojisi (tarihsel ve güncel boyutlarıla spor ve toplum). İstanbul: Başlık Yayınları.

Elden, M. \& Yeygel, S., (2006). Kurumsal Reklamın Anlattıkları. İstanbul: Beta Basım Yayım Dağıtım A.Ş.

Er, G., (2008). Sanal ortamda itibar yönetimi. İstanbul: Cinius Yayınları.

Gülnar, B., (2007). Örgütlerde iletişim ve iş doyumu. İstanbul: Literatürk

Gürgen, H., (1997). Örgütlerde iletişim kalitesi. İstanbul. Der Yayınları.

Güriz, D. \& Özdemir, G., (2007). İletişimci gözüyle insan kaynakları yönetimi. 3. Baskı. İstanbul: MediaCat Yayınlar1.

Katırcı, H., (2007). Spor kulüplerinde iletişim yönetimi: Türkiye profesyonel futbol liglerinde yer alan spor kulüplerinin iletişim uygulamalarına ilişkin araştırma. Doktora Tezi. Eskişehir. Anadolu Üniversitesi SBE.

İslamoğlu, A. H. \& Alnıaçı, Ü., (2013). Sosyal bilimlerde araştırma yöntemleri. 3. Baskı. İstanbul: Beta Basim.

Kasap, H. \& Kesim, Ü., (Ed.). (2007). Spor yönetimi. İstanbul: Beyaz Yayınları.

Okay, A., (2003). Kurum kimliği. 4.Baskı. İstanbul: Mediacat Yayınları.

Peltekoğlu, F., (2007). Halkla ilişkiler nedir? 5. Baskı. İstanbul: Beta Basım.

Sabuncuoğlu, Z. \& Gümüş, M., (2008). Örgütlerde iletişim. İstanbul: Arıkan Basım.

Tinaz, C., (2011). Türkiye’de sponsorluk etkisinin kontrolü ve farklı ölçüm tekniklerine göre durumun değerlendirilmesi. Doktora Tezi. İstanbul: Marmara Üniversitesi SBE.

Tutar, H., (2009). Örgütsel iletişim. 2. Baskı. Ankara: Seçkin Yayıncılık.

Uztuğ, F., Şener, G., Tokgöz, N., Bayçu, S., Yılmaz, A., \& Suher, İ., (2012). Kurumsal iletişim. Eskişehir: Anadolu Üniversitesi.

Yargıcı, E., (2010). Kurumsal iletişim yönteminde örgütlenme astrazeneca örneği. Yüksek Lisans Tezi. Kocaeli: Kocaeli Üniversitesi SBE.

Yıldırım, A. \& Şimşek, H., (2011). Sosyal bilimlerde nitel araştırma yöntemleri. 8. Baskı. Ankara: Seçkin Yayıncilık. 